\title{
A Pseudomonas aeruginosa Strain Ikw1 Produces an Unusual Polymeric Surface-Active Compound in Waste Frying Oil-Minimal Medium
}

\author{
Maurice George Ekpenyong ${ }^{1}$, Sylvester Peter Antai' ${ }^{2}$, Atim \\ David Asitok ${ }^{3}$
}

Environmental Microbiology and Biotechnology Unit, Department of Microbiology, Faculty of Biological Sciences, University of Calabar, P.M.B.1115 Calabar, Nigeria

\begin{abstract}
A Gram-negative bacterium isolated from the sub-surface water of Ikang River, Niger Delta region, Nigeria produced an unusual biosurfactant in waste frying oil-minimal medium. Cultural and biochemical characterizations as well as 16S rRNA sequencing identified the bacterium as a strain of Pseudomonas aeruginosa with 100\% sequence homology with Pseudomonas aeruginosa strain HNYM41. Biochemical characterizations, thin layer chromatography (TLC), high performance liquid chromatography (HPLC) and Fourier transform-infrared (FTIR) spectrometry identified the active compound as a glycolipopeptide (peptidoglycolipid) composed of $40.36 \%$ carbohydrates, $20.16 \%$ proteins and $34.56 \%$ lipids. The biosurfactant reduced surface tension of water from 72.00 to 24.62 dynes/cm at a critical micelle concentration (CMC) of $20.80 \mathrm{mg} / \mathrm{L}$ indicating excellent effectiveness and efficiency properties. Commendable oil-washing property $(79.92 \%$ oil recovery) with an elution rate of $0.68 \mathrm{~mL} / \mathrm{min}$ at $70^{\circ} \mathrm{C}$, foaming and foam stability, excellent emulsification activity in kerosene, crude oil and palm oil and a significant $\left(P=0.000 ; R^{2}=0.9901\right)$ oil solubilization property indicate excellent oil recovery, detergency and remediation potentials of the biosurfactant. Oil displacement, emulsifying and antimicrobial activities of the compound were relatively stable at relevant temperatures, $\mathrm{pH}$ and $\mathrm{NaCl}$ levels suggesting suitability for applications in hydrophobic compound remediation, emulsion stabilization and preservation of formulations.
\end{abstract}

Keywords: Pseudomonas aeruginosa strain IKW1, glycolipopeptide, enhanced oil recovery, emulsification, stability

\section{Introduction}

Surface active compounds, otherwise called surfactants, are amphiphilic molecules with hydrophilic and hydrophobic domains which reduce the free surface enthalpy per unit area [1] at air/water interfaces and the interfacial tension at oil/water interfaces [2]. They are about the most sought-after process chemicals worldwide. Their applications range from agriculture and environment [3] [4] to industries including food, cosmetics and pharmaceuticals not to mention petroleum [5]. These applications derive from their nature and the physicochemical properties which determine their various types including glycolipids, lipopeptides, neutral lipids, phospholipids and the polymeric types [6]-[8].

Synthetic chemistry is at the forefront of production of these molecules derived predominantly from petrochemicals which make them cheap and commercially available [9]. Nevertheless, the bulk applications of these chemicals especially in environmental bioremediation [10] [11] and to a lesser extent, the industries, whose effluents still end up in the environment, have been a source of environmental concern owing to their toxicity and environmental incompatibility [7].

Green surfactants or biologically-derived surfaceactive molecules, especially those of microbial origin called biosurfactants, are suitable alternatives to their chemical counterparts by reason of their wider applications, biodegradability, low to non-toxicity and environmental compatibility [12]. Biosurfactantproducing microbial strains from different taxonomic groups especially bacteria [13] [14] and yeasts [15] [16] have been isolated and employed in production. In recent times, a new area, called green chemistry,

This article is published under the terms of the Creative Commons Attribution License 4.0 Author(s) retain the copyright of this article. Publication rights with Alkhaer Publications.

Published at: http://www.ijsciences.com/pub/issue/2016-06/

DOI: 10.18483/ijSci.1064; Online ISSN: 2305-3925; Print ISSN: 2410-4477 
has been developed where biosurfactants are applied in the production of nanoparticles [17].

In the industries, most of the biosurfactants are used as emulsifiers but extensive applications in this respect have been limited by relatively high production and recovery costs [1]. Production economics is frequently encountered as the major drawback of biotechnological processes including biosurfactant production and has greatly limited its commercial applications. However, production costs can be reduced by careful selection of producing strains with improved yield, improved product formation rates and use of cheap (often waste) substrates. Recommended protocol for isolation of biosurfactant-producing bacteria involves a combination of screening concepts [18]. However, multiple substrates are required for successful isolation and selection of a diversity of biosurfactantproducing bacteria with abilities to produce novel biosurfactant types [13]. The successful use of wastes like olive oil mill effluent, dairy waste and waste frying oil as substrates for biosurfactant production has been reported by few researchers and with encouraging results [19]-[21].

Here, we report the isolation of a strain of Pseudomonas aeruginosa from the mesotidal waters of Ikang River, Niger Delta area, Nigeria, with ability to elaborate an unusual surface-active compound when grown on waste frying sunflower oil. A waste frying oil disposal problem currently exists in Calabar, the capital city of Cross River State, Nigeria, where it is emptied into drainages resulting in unbearable stench in the capital city. Government has already shut down a number of fast foods in the city thereby worsening the unemployment problem of the state and country. Utilization of the waste frying oil for biosurfactant production will go a long way to solving waste oil disposal and subsequently unemployment problems. To the best of our knowledge, this is the third time a strain of Pseudomonas aeruginosa has been reported to produce a glycolipopeptide biosurfactant but the first report of that production on waste frying oil.

\section{Materials and methods}

\subsection{Collection of morphologically-distinct bacteria}

Morphologically-distinct bacteria were isolated from 20 samples comprising surface-water (5), soil (5), sediment (5), crude oil reservoir-water (3) and Nigerian light crude oil sample (2), on Tryptic Soy agar (TSA) medium by the pour plate technique.

\subsection{Screening of bacteria for biosurfactant production}

2.2.1. Medium formulation for biosurfactant production
Purified cultures of all morphologically-distinct bacteria were grown in minimal medium supplemented with different carbon sources including glucose, glycerol, rice processing effluent, crude oil and waste frying oil at $1 \%(\mathrm{v} / \mathrm{v}$ or w/v) as sole source of carbon and energy. The minimal medium $\begin{array}{llllll}\text { contained } & (\mathrm{g} / \mathrm{L}) & \mathrm{KH}_{2} \mathrm{PO}_{4} & 1.0 ; & \mathrm{K}_{2} \mathrm{HPO}_{4} & 0.5 \text {; }\end{array}$ $\mathrm{MgSO}_{4} .7 \mathrm{H}_{2} \mathrm{O} 0.2 ; \mathrm{NaCl} 0.5 ; \mathrm{NH}_{4} \mathrm{Cl} 1.0 ; \mathrm{FeSO}_{4} .7 \mathrm{H}_{2} \mathrm{O}$ 0.01 with $\mathrm{pH}$ adjusted to 7.0 using $1 \mathrm{M} \mathrm{HCl} / \mathrm{IM}$ $\mathrm{NaOH}$. Twenty milliliter volume of minimal medium was dispensed into $100 \mathrm{~mL}$ Erlenmeyer flasks. Flasks were sterilized by autoclaving at $121^{\circ} \mathrm{C}$ for $15 \mathrm{~min}$ and inoculated, upon cooling, with $2 \%$ (v/v) 18 h-old Luria broth culture of each bacterial isolate. Flasks were incubated at room temperature $\left(28 \pm 2{ }^{\circ} \mathrm{C}\right)$ on a rotary shaker agitating at $150 \mathrm{rpm}$ for $72 \mathrm{~h}$.

\subsubsection{Qualitative screening of isolates for biosurfactant production}

Cell-free fermentation broth of each flask corresponding to each bacterium was obtained by centrifugation at $8,000 \mathrm{x} \mathrm{g}$ for $10 \mathrm{~min}$ followed by membrane filtration with $0.2 \mu \mathrm{M}$ (Millipore) and subjected to qualitative screening for biosurfactant production by the combination of rapid drop collapse test [13], emulsifying activity test [22], salt aggregation test [23] and oil displacement test [6].

\subsubsection{Quantitative biosurfactant screening}

The initial quantification of biosurfactant in cell-free broth of bacteria which tested positive to at least $75 \%$ of the qualitative screen tests followed the oildisplacement assay. This assay is sensitive enough to detect the presence of $10 \mu \mathrm{g}$ or $10 \mathrm{nmol}$ of biosurfactant in sample solutions [6]. In this test, 15 $\mu \mathrm{L}$ of crude oil (Nigerian medium crude-Adaax) was added to the surface of $40 \mathrm{~mL}$ of distilled water in a Petri dish of diameter $15 \mathrm{~cm}$ to form a thin uniform oil layer. Plates were allowed to equilibrate for $1 \mathrm{~h}$. Thereafter, $10 \mu \mathrm{L}$ of each cell-free fermentation broth was gently placed on the center of the oil layer. The diameter of clear halo visualized under visible light was measured with a meter rule after $30 \mathrm{~s}$ and area of clear zone calculated using the formula $\mathrm{A}=\pi \mathrm{r}^{2}$; where $\mathrm{A}$ is the area of the oil film, $\mathrm{r}$ the radius and $\pi$ a constant of value 3.14. The larger the diameter of clear halo, the larger the area and hence the greater the amount of biosurfactant. All determinations were made in triplicates. Biosurfactant hyper-producing strains were selected by consideration of mean oildisplaced areas of their cell-free fermentation broth.

\subsection{Identification of biosurfactant -producing bacterium \\ The selected bacterium was identified morphologically and biochemically using the MICROGEN ID Kit (Microgen Bioproducts Limited, UK) in conjunction with Microgen identification system software as well as by $16 \mathrm{~S}$ rRNA sequencing.}


The sequencing protocol made use of primers 271 and 1492R and utilized a sequence mix composed of NZYTaq 2 x Green Master Mix (Nzytech). Amplification was done by denaturation at $94^{\circ} \mathrm{C}$ for 3 min, cooling to $5^{\circ} \mathrm{C}$ for $1 \mathrm{~min}$ and raising the temperature again to $72^{\circ} \mathrm{C}$. This was repeated through 30 cycles and then held at $72^{\circ} \mathrm{C}$ for $10 \mathrm{~min}$. The polymerase chain reaction (PCR) products were purified with the JETQUICK PCR purification Spin Kit and used as template for the sequencing reaction. Sequences were compared to GenBank sequences by using standard nucleotide basic local alignment search tool (BLAST). The bacterium was deposited at the University of Calabar collection of Microorganisms (UCCM) and had since been given the collection's code name.

2.4. Determination of the effectiveness of biosurfactants by surface tension reduction measurement

The surface tensions of sterile clear amber cell-free biosurfactant solutions of four isolates were determined by the ring method [20] at room temperature with a tensiometer (CSC Du-Nouy Tensiometer) fitted with a platinum ring. A volume of $70 \mathrm{~mL}$ of each cell-free biosurfactant broth was dispensed into $100 \mathrm{~mL}$ beakers and placed on the seat of the tensiometer. The seat was then raised by an adjustment knob until contact was made between the surface of biosurfactant liquid and the platinum ring. The liquid film produced beneath the ring was stretched as attempt was made to bring the ring out of the liquid by means of the adjustment knob. The force needed to break the ring free of the liquid to the surface was read off a scale calibrated in dynes $/ \mathrm{cm}$. This was repeated 5 times for each of the biosurfactant solutions and mean determinations obtained and presented as surface tension of biosurfactants from the bacterial strains tested.

\subsection{Recovery and characterization of biosurfactant \\ 2.5.1 Biosurfactant recovery}

Most effective biosurfactant was recovered from the sterile clear amber liquid (obtained by centrifugation of fermentation broth at $8,000 \times \mathrm{x}$ for $10 \mathrm{~min}$ followed by sterilization by membrane filtration) by acidification of $5 \mathrm{~mL}$ sterile biosurfactant solution to pH 2.0 with $6 \mathrm{~N} \mathrm{HCl} \mathrm{[24].} \mathrm{Thereafter,} \mathrm{acidified}$ biosurfactant treatments were allowed to stand for 10 $\mathrm{h}$ at $4^{\circ} \mathrm{C}$ after which equal volumes of the acid-treated biosurfactant and chloroform-methanol mixture (2:1) were prepared in separatory funnels The preparations were allowed to stand for $30 \mathrm{~min}$ and the bottom layer (organic phase) separated and subjected to rotary evaporation at $35^{\circ} \mathrm{C}$. The brown oily substance that ensued was weighed and expressed as $\mathrm{g} / \mathrm{L}$.

\subsubsection{Structural characterization of}

\section{biosurfactant}

\subsubsection{Biochemical characterization}

Total carbohydrate in the crude biosurfactant solution was determined by the phenol-sulfuric acid method [25] using glucose (Merck) as standard. Total protein was determined by the Bradford method [26] using bovine serum albumin (Research Organics, USA) as standard. Total lipids was detected and quantified as described by the method of Folch et al. [27].

\subsubsection{Biosurfactant analysis by Thin Layer Chromatography (TLC)}

The crude biosurfactant isolated in sub-section 2.4.1 was dissolved in chloroform and spotted on TLC plates made of silica gel. The developing solvent was a mixture of chloroform: methanol: water $(65: 25: 4)$. Retention factors were calculated after spots were noted and visualized under UV lamp. The plates were then sprayed with different reagents for the detection of different chemical molecules. Some plates were sprayed with H2SO4 :Methanol (5:85) mixture [13] for the detection of carbohydrates followed by heating at $125^{\circ} \mathrm{C}$. Some were steamed in iodine vapour for the detection of lipids (fatty acids) and some sprayed with ninhydrin reagent containing $0.5 \mathrm{~g}$ ninhydrin in $100 \mathrm{~mL}$ anhydrous acetone for the detection of peptides (proteins). Negative ninhydrin tests prompted digestion of biosurfactant with $6 \mathrm{~N}$ $\mathrm{HCl}$ followed by heating to $105^{\circ} \mathrm{C}$ for $24 \mathrm{~h}$ for the detection of free amino acids [28] and the ninhydrin test repeated. Spot colour was noted. Surface active fractions were confirmed by oil displacement activity of needle-point scrapings from the plates.

\subsubsection{Biosurfactant analysis by high performance liquid chromatography (HPLC)}

The active fractions of crude biosurfactant obtained from analytical TLC were subjected to HPLC analysis using a Gemini $\mathrm{C}_{18}$ column $(100 \times \mathrm{x} 4.6 \mathrm{~mm})$ with a particle diameter of $5 \mu \mathrm{M}$ accompanied with a Varian 335 diode array detector to facilitate UV detection over a wavelength range of 200 and 220 nM. Sample analysis followed a linear gradient with $85 \%$ eluent A comprising of $0.1 \%$ ortho-phosphoric acid and $15 \%$ eluent $B$ made of acetonitrile at $0 \mathrm{~min}$, only to increase eluent B to $100 \%$ after $40 \mathrm{~min}$ at an eluent flow rate of $1.0 \mathrm{~mL} / \mathrm{min}$ [29].

\subsubsection{Biosurfactant analysis by Fourier transform-Infrared (FT-IR) spectrometry \\ The infrared spectra of the partially-purified biosurfactant were recorded on a Fourier transform- infrared system (Spectrum BX-Perkin Elmer) in the $4000-400 \mathrm{~cm}^{-1}$ spectral region at $2 \mathrm{~cm}^{-1}$ resolution. The sample was spread on $0.23 \mathrm{~mm} \mathrm{KBr}$ cell and cell inserted into the IR transforming system. The spectra were displayed on a connecting computer monitor after Fourier-transformation.}




\subsection{Evaluation of biosurfactant effectiveness and efficiency}

The effectiveness of the crude biosurfactant, given by surface tension reduction, was determined by the ring method [20] at room temperature with a tensiometer (CSC Du-Nouy Tensiometer) fitted with a platinum ring. The efficiency of the biosurfactant, given by its critical micelle concentration, CMC was determined by measuring surface tension values of increasing concentrations of the biosurfactant. The logtransformed biosurfactant concentrations were regressed on their respective surface tension values using a second-order polynomial function. The CMC was defined as the minimum biosurfactant concentration above which no further reduction in surface tension occurred.

2.7. Activity characterization of biosurfactant 2.7.1. Biosurfactant-enhanced oil recovery (washing activity) by the sand pack method

Biosurfactant enhanced recovery of Bonny light crude oil was conducted using the modified sand pack column technique [30]. One hundred and fifty grams $(150 \mathrm{~g})$ of $140 \mu \mathrm{M}$ size sand particle was packed into a glass column of $20 \mathrm{~mm} \times 25 \mathrm{~mm} \times 85$ $\mathrm{mm}$ dimensions with a $100 \mu \mathrm{M}$ pore size sieve. The column was fitted with a tap outlet at the bottom to permit escape of recovered oil. A volume of $100 \mathrm{~mL}$ of Nigerian medium crude oil was poured into the column and allowed to stand for $3 \mathrm{~h}$. Then $100 \mathrm{~mL}$ of sterile biosurfactant solution was added to the column and the column incubated at 30,50 and $70^{\circ} \mathrm{C}$ to ascertain temperature influence on biosurfactantenhanced recovery. The experiment was set up in triplicates with $50 \mathrm{~mL}$ of Milli-Q water serving as control. Volume of oil released by biosurfactant enhancement was measured at 30 min interval for $3 \mathrm{~h}$ at the different temperatures and compared with that of the control. Oil recovery rate was determined and expressed as $\mathrm{mL} / \mathrm{min}$.

\subsubsection{Biosurfactant-enhanced solubilization of Nigerian medium crude}

Crude oil solubilization test was performed following a batch solubilization technique [31]. Twenty-five milliliters $(25 \mathrm{~mL})$ of Nigerian medium crude oil (ADAAX Oil Nigeria) and different concentrations of crude biosurfactant $(0,50,100,200,300,500$, $700,1000,1300,1650$ and $2000 \mathrm{mg} / \mathrm{L})$ solutions were mixed in equal volumes in glass-stoppered 250 $\mathrm{mL}$ Pyrex separatory funnel. The funnels were placed on a rotary shaker agitating at $200 \mathrm{rpm}$, at $30^{\circ} \mathrm{C}$ for $36 \mathrm{~h}$. A $12 \mathrm{~h}$ settling period was allowed followed by withdrawal of the aqueous phase from the bottom of the funnel with minimal disturbance. Samples, now called water soluble fractions (WSF), were analyzed for total petroleum hydrocarbons (TPH) by the nhexane method. Absorbances of n-hexane extracts from the different treatments were taken at $450 \mathrm{~nm}$ with HACH DR 300 Spectrophotometer and amounts determined gravimetrically from a standard curve. Regression statistics (Excel 2007) was used to analyze data obtained to show relationship between biosurfactant concentration and solubilization of crude oil at $95 \%$ confidence limit.

\subsubsection{Assessment of antimicrobial activity of biosurfactant}

Assessments were conducted by the agar disc diffusion method [28] in Muller-Hinton agar for bacteria and Potato dextrose agar for fungi. Discs of $6 \mathrm{~mm}$ size were punched from filter paper (Whatman No 3; Millipore) and sterilized by autoclaving in capped bottles. Aliquots of $20 \mu \mathrm{L}(50 \mu \mathrm{g} / \mathrm{mL})$ of crude biosurfactant solution were absorbed by each disc and allowed to equilibrate for $24 \mathrm{~h}$. Equilibrated discs were aseptically introduced onto the center of Muller-Hinton and Potato dextrose agar plates preseeded with appropriate dilutions of test cultures/spores. Cell/spore densities of test cultures were as follows $(\mathrm{cfu} / \mathrm{mL}) ; 10^{6}$ for Bacillus subtilis UCCM 0006, $10^{7}$ for Micrococcus sp. UCCM 0011, Rhodotorula mucilaginosa UCCM 0014 and Candida sp. UCCM 0013, $10^{8}$ for Serratia sp. UCCM 0003, Chromobacterium violaceum UCCM 0001, Rhizopus stolonifer UCCM 0010 and Penicilium frequentans UCCM 0015. Antimicrobial potential of biosurfactant was indicated by the appearance of inhibition zone within $48 \mathrm{~h}$. Zone diameters were measured with meter rule and expressed in $\mathrm{mm}$. All preparations were made in triplicates and mean zone diameters calculated.

\subsubsection{Measurement of emulsifying activity of biosurfactant}

The emulsifying property was measured as described in Asitok and Antai [22] and results expressed as per cent E24 (\% E24). Kerosene, Nigerian medium crude oil and palm oil served as hydrophobic compounds.

\subsubsection{Assessment of foaming property of biosurfactant}

The foam power and stability of the glycolipopeptide was evaluated according to the method of Chen et al. [32] with slight modifications. A volume of $200 \mathrm{~mL}$ of sterile biosurfactant solution was allowed to flow through a burette from a height of $90 \mathrm{~cm}$ into a 500 $\mathrm{mL}$ measuring cylinder. The turbulence generated foam whose height was noted immediately and then after $5 \mathrm{~min}$. Foam heights were also measured every $1 \mathrm{~h}$, then every $24 \mathrm{~h}$. The foam height at time $0 \mathrm{~min}$ was considered the foam power while the R5, defined as the ratio of the foam height at time 5 min to that at time $0 \mathrm{~min}$, was considered an indication of foam stability.

2.8. Stability characterization of biosurfactant 2.8.1. Temperature stability 
To determine the thermal stability of a $5 \mathrm{~g} / \mathrm{L}$ crude biosurfactant solution, the test biosurfactant preparation was maintained at temperatures of 20, 40, $60,80,100,120,130$ and $140^{\circ} \mathrm{C}$ for $15 \mathrm{~min}$, cooled at room temperature and oil displacement, emulsification and antimicrobial activity tests of the glycolipopeptide performed as described by Abouseoud et al. [33].

\subsection{2. pH stability}

The effect of $\mathrm{pH}$ on biosurfactant activity was performed by adjusting the $\mathrm{pH}$ of $5 \mathrm{~mL}$ of $0.5 \%(\mathrm{w} / \mathrm{v})$ crude biosurfactant solution with $1 \mathrm{M} \mathrm{HCl} / 1 \mathrm{M} \mathrm{NaOH}$ through a range from 4 to 11 and held for $15 \mathrm{~min}$. Oil displacement, emulsification and antimicrobial activity tests of the glycolipopeptide were conducted as described previously [33].

\subsubsection{Salinity $(\mathrm{NaCl})$ stability}

Crude biosurfactant concentration of $0.5 \%(\mathrm{w} / \mathrm{v})$ was prepared by dissolving $0.5 \mathrm{~g}$ of crude biosurfactant in $100 \mathrm{~mL}$ of different concentrations of $\mathrm{NaCl}$ solution. The concentrations used included 5, 10, 15, 20 and $25 \%$ at a $\mathrm{pH}$ of 7.0 . The preparations were held at $30^{\circ} \mathrm{C}$ for $15 \mathrm{~min}$ to determine the effect of salt concentrations on activities of the glycolipopeptide. Oil displacement, emulsification and antimicrobial activity tests were performed as previously described [33].

\section{Results}

\subsection{Substrate-specific isolation of} biosurfactant-producing bacteria

The results of isolation of biosurfactant-producing bacteria from the 20 samples analyzed in our study, as mediated by the different substrates, are presented in Table 1. The table reveals that a total of 858 morphologically-distinct bacteria were isolated from all 20 samples with Ifondo water (IFW) harboring the highest number of distinct bacteria of 69 . The table also reveals that a total of 141 (16.43\%) biosurfactant-producing bacteria were selected using different substrates with waste-frying oil contributing $50(35.46 \%)$. Generally, miscible substrates selected fewer biosurfactant-producing bacteria than hydrophobic substrates. A two-way analysis of variance revealed significant $(\mathrm{P}<0.05)$ influence of substrates on the isolation of biosurfactant-producing bacteria.

\subsection{Quantitative screening for industrially- relevant biosurfactant-producing bacteria}

Table 2 presents the results of the quantitative screening of primarily positive biosurfactantproducing bacteria from the three major kinds of samples. The results show that only $28(19.59 \%)$ of the total biosurfactant-producing bacteria were truly positive for biosurfactant production by the oil displacement assay method. Mean oil-displaced areas of 4 best isolates were IKW1 $\left(66.5 \mathrm{~cm}^{2}\right)>\operatorname{IFW}(55.3$ $\left.\mathrm{cm}^{2}\right)>$ OB6 $\left(52.8 \mathrm{~cm}^{2}\right)>\operatorname{R} 15 \mathrm{~B}\left(50.3 \mathrm{~cm}^{2}\right)$. Results also show very clearly that $3(75 \%)$ of the best isolates were obtained from water samples.

\subsection{Identification of biosurfactant-producing bacteria}

A summary of the results of characterization tests leading to the identification of the best 4 biosurfactant-producing bacteria is presented in Table 3. The table reveals that isolate IKW1 was Pseudomonas aeruginosa with a $100 \%$ sequence homology with Pseudomonas aeruginosa strain HNYM41 with a GeneBank accession number of JN999891A. Isolate R15B, on the other hand, was identified as Bacillus cereus with a $100 \%$ sequence homology with Bacillus cereus strain F2 with an accession number of JQ579629A. The table also reveals that $3(75 \%)$ of the 4 best biosurfactantproducing bacteria were Gram-negatives.

\subsection{Surface tension reduction (effectiveness) potentials of biosurfactants}

Investigation into the effectiveness potentials of surface-active compounds of Pseudomonas aeruginosa strain IKW1, Pseudomonas flourescens strain IFW3, Pseudomonas sp. strain OB6 and Bacillus cereus strain R15B revealed that Pseudomonas aeruginosa IKW1 biosurfactant was the most effective and could reduce surface tension of water from 72 dynes/cm to 24.62 dynes/cm while the least effective was that from Pseudomonas sp. strain OB6 which only reduced surface tension from 72 dynes/cm to 35.58 dynes/cm.

\subsection{Recovery and identification of Pseudomonas aeruginosa Strain IKW1 biosurfactant}

Among the 5 organic solvents and their mixtures employed for biosurfactant recovery after precipitation by acidification, the solvent mixture of chloroform-methanol (2:1) recovered the highest biosurfactant amount of $4.39 \mathrm{~g} / \mathrm{L}$. Biochemical characterizations of the biosurfactant revealed that the surface-active compound was composed of carbohydrates, proteins and lipids with percent compositions of 40.36, 20.16 and $32.56 \%$ respectively. This chemical composition was confirmed by the results of the analytical thin layer chromatographic analysis which revealed 3 active fractions from the chloroform:methanol:water $(65: 25: 4)$ mixture, their activities of which were confirmed by oil displacement assay. The retention factors (Rf) of the fractions F1, F2 and F3 were 0.45, 0.33 and 0.73 respectively. F1 and F3 stained yellow upon spraying with $\mathrm{H}_{2} \mathrm{SO}_{4}$ :methanol (5:85) mixture confirming the presence of carbohydrates in these fractions. F2 fraction stained red when the plates were heated in iodine vapour confirming the presence 
of lipids in the fractions. Original ninhydrin spray was negative as no colour developed from any of the fractions suggesting the presence of blocked $\mathrm{N}$ terminal. Digesting the biosurfactant with $\mathrm{HCl}$ and repeating the TLC procedure, caused the F2 fraction with $\mathrm{Rf}=0.33$ to turn red when ninhydrin was sprayed on it indicating the presence of free amino acids.

The high performance liquid chromatography (HPLC) analysis of preparatory thin layer chromatographic fractions revealed just one peak indicating that the biosurfactant was purified to $95 \%$ purity level.

Figure $\mathbf{1}$ is the spectrum of Fourier transforminfrared (FT-IR) spectrometry of the surface-active compound of Pseudomonas aeruginosa strain IKW1. The figure reveals the presence of $\mathrm{C}-\mathrm{H} / \mathrm{O}-\mathrm{H}$ stretch bands at wave number between 3765 and $3367 \mathrm{~cm}^{-1}$ indicating the presence of aldehydes in carbohydrates. $\mathrm{C}-\mathrm{H}$ asymetric vibrations of $\mathrm{CH}_{2}$ and $\mathrm{CH}_{3}$ were observed at $2926 \mathrm{~cm}^{-1}$ and $2868 \mathrm{~cm}^{-1}$ suggesting the presence of alkanes in lipids. This was confirmed by the presence of deformation vibrations at $1456 \mathrm{~cm}^{-1}$. The characteristic stake-shaped band for $\mathrm{N}-\mathrm{H} / \mathrm{C}=\mathrm{O}$ bond was observed at $1712 \mathrm{~cm}^{-1}$ indicating the presence of amino and carboxylic groups. These characteristics, in combination with biochemical and chromatograhic results strongly suggest carbohydrate (glyco), lipid (lipo) and protein (peptide) composition for this biosurfactant. The surface-active compound could therefore be safely referred to as a glycolipopeptide (or a peptidoglycolipid).

\subsection{Determination of glycolipopeptide efficiency with the critical micelle concentration (CMC)}

The efficiency of the glycolipopeptide biosurfactant, given by its critical micelle concentration (data not shown) revealed that the glycolipopeptide has a CMC of $20.80 \mathrm{mg} / \mathrm{L}$. The second order polynomial used to fit the regression model revealed a significant goodness-of-fit $(P=$ $\left.0.000 ; R^{2}=0.9683\right)$ of the model.

\subsection{Enhanced oil recovery (washing activity), solubilization, emulsification and foaming activities of glycolipopeptide}

Results of the sand pack experiment demonstrating the oil recovery potential of the glycolipopeptide (data not shown) revealed that highest recovery rate of crude oil of $0.87 \mathrm{~mL} / \mathrm{min}$ occurred at $50^{\circ} \mathrm{C}$ at $120^{\text {th }}$ min of incubation. Biosurfactant-enhanced recovery rate of crude oil at $30^{\circ} \mathrm{C}$ increased linearly with time until it peaked at $0.63 \mathrm{~mL} / \mathrm{min}$ at $150^{\text {th }} \mathrm{min}$. A nearperfect parabolic curve with a peak of $0.68 \mathrm{~mL} / \mathrm{min}$ at $90 \mathrm{~min}$ was attained when temperature was raised to $70^{\circ} \mathrm{C}$ with an oil recovery effectiveness of $79.92 \%$. Only $21.37 \%$ of oil was recovered with Milli-Q water (control) with a constantly increasing recovery rate throughout the $3 \mathrm{~h}$ holding time.

The results of the solubilization potentials of the glycolipopeptide revealed significant $(P<0.05)$ positive linear relationship $\left(R^{2}=0.9901\right)$; oil solubilization increasing as biosurfactant concentration increased.

Emulsifying activity of the glycolipopeptide was tested with kerosene, crude oil and palm oil as hydrophobic compounds. The results showed that emulsification indices of the surface-active compound were $79.71 \%, 84.87 \%$ and $87.54 \%$ in kerosene, crude oil and palm oil respectively.

Results of the foaming property experiment of the biosurfactant revealed that the active compound could produce small densely-packed foam with a height of $7.2 \pm 0.3 \mathrm{~cm}$ at time $0 \mathrm{~min}$. The foam was stable for $>48<72 \mathrm{~h}$. R5 of the foam was 1 .

\subsection{Antimicrobial}

potential

of glycolipopeptide

The results of the antimicrobial potentials of the glycolipopeptide showed that the biosurfactant could most inhibit Bacillus subtilis UCCM 0006 to a zone diameter of $34 \mathrm{~mm}$. However, the surface-active compound showed no inhibitory activity against Serratia sp.UCCM 0003. Overall spectrum of antimicrobial coverage of the glycolipopeptide was narrow.

\subsection{Stability characterization of} glycolipopeptide activities

The results of the effect of temperature, $\mathrm{pH}$ and $\mathrm{NaCl}$ on the oil displacement activity of the glycolipopeptide are presented in Figure 2. Figure $\mathbf{2 A}$ reveals that oil displacement activity of the glycolipopeptide was stable up to $80^{\circ} \mathrm{C}$ after which it dropped gradually. The glycolipopeptide was observed, in Figure 2B, to be stable at alkaline $\mathrm{pH}$ levels with maximal stability of oil displacement activity at $\mathrm{pH}$ between 7 and 9 . The oil displacement activity of the surface-active compound in Figure 2C was decreased gradually with increase in $\mathrm{NaCl}$ concentrations. $\mathrm{NaCl}$ concentration of up to $10 \%$ still demonstrated commendable displacement activity.

Results of the effect of temperature, $\mathrm{pH}$ and $\mathrm{NaCl}$ on the emulsifying activity of the glycolipopeptide are presented in Figure 3. Figure 3A shows that the emulsifying activity of the glycolipopeptide increased as temperature increased. An activity of $79.71 \%$ at $30^{\circ} \mathrm{C}$ in kerosene increased to $91.43 \%$ at $140^{\circ} \mathrm{C}$ while that of $82.87 \%$ in palm oil increased to $95.49 \%$ at $140^{\circ} \mathrm{C}$. Figure 3B shows the influence of $\mathrm{pH}$ on the 
emulsifying activity of the biosurfactant and reveals that the activity increased as the $\mathrm{pH}$ increased from 4 to 7 and stabilized at the alkaline region. The influence of $\mathrm{NaCl}$ on the emulsifying activity of the biosurfactant is shown in Figure 3C and reveals that $77.21 \%$ of the emulsifying activity was retained at $10 \% \mathrm{NaCl}$.

Figure 4 is a presentation of the results of the effect of temperature, $\mathrm{pH}$ and $\mathrm{NaCl}$ concentrations on the antimicrobial activity of the glycolipopeptide. Figure 4A shows that the antimicrobial activity was retained up to $60^{\circ} \mathrm{C}$ and reduced after that until $140^{\circ} \mathrm{C}$. Figure 4B shows that the antimicrobial activity of the surface-active compound was high at acidic and extremely alkaline $\mathrm{pH}$ but was moderate at neutral and weakly alkaline $\mathrm{pH}$ ( 8 to 9 ). The influence of $\mathrm{NaCl}$ concentrations on the antimicrobial activity of the biosurfactant is presented in Figure 4C and reveals that the activity remained stable up to $10 \%$ $\mathrm{NaCl}$ concentration but gradually decreased at higher $\mathrm{NaCl}$ concentrations.

\section{Discussion}

The results of this study are very emphatic on the influence of carbon substrates on the isolation of biosurfactant-producing bacteria as opposed to its influence on microbial selection for an industrial process. Our results show significant $(P<0.05)$ influence of substrates on isolation or distribution of biosurfactant-producing bacteria from/in the samples but non-significant $(P>0.05)$ influence of nature of samples on the same property. This infers that whatever the nature of sample, a tendency exists to isolate a biotechnologically-relevant biosurfactantproducing organism if the substrate in the screening medium appropriate for the organism. These results ratify the suspicions of Bodour et al. [13] that nature of carbon substrates is a major reason for the difficulty encountered in the many attempts at isolating biosurfactant-producing bacteria from samples.

The substrate-dependence of biosurfactant elaboration by bacteria in particular and microbes in general is borne out of the different physiological roles to which the producing organism puts the surface-active agent post-synthesis. It would be strange for a bacterium to elaborate biosurfactants for solubilization when a highly soluble substrate like glucose is the carbon source in the screening medium. If the organism did, then the biosurfactant would be for a purpose other than solubilization. The dominant selection of $29(54.72 \%)$ biosurfactantproducing strains when waste frying sunflower oil served as carbon substrate in the screening medium suggests its better nutrient level and/or mix which directs biosurfactant synthesis in most of the bacteria. Successful production of biosurfactants in waste frying oil has been covered in the review by Makkar and colleagues [34]. Only few reports exist in the use of waste frying oil for biosurfactant production and even fewer for isolation of biosurfactant-producing bacteria in nature.

True biosurfactant-producing bacteria were confirmed in our study from a combination of four qualitative tests in addition to the rapid drop collapse test. The ability of an organism to test positive for biosurfactant-production in one screening method but fail in another suggests diversity in physiological roles of biosurfactants and their very chemical nature. For instance, diffusion restraints in blood agar may not allow high molecular weight biosurfactants to be detected by blood cell hemolysis [20]. Mabrouk et al. [18] combined four different methods to be able to isolate the glycolipopeptide-producing Bacillus sp. E34. The need for multiple substrates for successful isolation of biosurfactant-producing bacteria underscores both the tedion involved in biosurfactant bio-prospecting and the unpredictability of appropriateness of selection protocols in industrial organism search.

The results of the quantitative screening assessed by the method of oil displacement present a rather interesting trend. The method was selected by reason of the significant $\left(P=0.000 ; R^{2}=0.9997\right)$ linear relationship between area of displaced oil and amount of surface-active compound demonstrated by sodium dodecyl sulphate (SDS). This strong relationship had earlier been reported by Satpute et al. [14]. Apart from ES2 isolated from Eketai sediment sample, the immediate 9 most efficient biosurfactant-producing bacteria were obtained from water or crude-oil samples suggesting the physiological need for bulk production of the surface-active agents in liquid media/systems which compensates naturally for the dilution effect of the liquid environment.

The best 4 biosurfactant-producing bacterial species namely Pseudomonas aeruginosa Strain IKW1, Pseudomonas sp. Strain OB6, Pseudomonas fluorescens Strain IFW3 and Bacillus cereus Strain $\mathrm{R} 15 \mathrm{~B}$ are not new to biosurfactant research and have been copiously documented [35]. The 100\% sequence homology of Pseudomonas aeruginosa strain IKW1 and Bacillus cereus Strain R15B with Pseudomonas aeruginosa Strain HNYM41 and Bacillus cereus Strain F2 respectively, suggests that these strains are the same but there has been no report on the biosurfactant-producing potentials of these bacteria.

The effectiveness of a biosurfactant is given by its measure of surface/or interfacial tension reduction. Pseudomonas aeruginosa Strain IKW1 surface-active compound reduced the free surface enthalpy per unit 
area of water from 72 dynes/cm to 24.62 dynes $/ \mathrm{cm}$ thus capable of bringing $65.44 \%$ of hydrophobic substances into solution to form emulsion. The second best surface-active compound obtained from Bacillus cereus Strain R15B was able to reduce surface tension from 72 dynes/cm to 29.40 dynes $/ \mathrm{cm}$. The most powerful biosurfactant, surfactin, was reported to reduce the surface tension of water to $27.50 \mathrm{mN} / \mathrm{m} \mathrm{[7]} \mathrm{thus,} \mathrm{making} \mathrm{the} \mathrm{active} \mathrm{compound}$ from Pseudomonas aeruginosa Strain IKW1in this study a more effective biosurfactant.

The efficiency of a biosurfactant is, on the other hand, given by its critical micelle concentration; defined as the minimum concentration of the biosurfactant above which no further reduction in surface tension occurs and supramolecular structures like micelles and bi-layers form. In this study, the critical micelle concentration $(\mathrm{cmc})$ of the surfaceactive compounds of Pseudomonas aeruginosa Strain IKW1 and Bacillus cereus Strain R15B were 21 and $12 \mathrm{mg} / \mathrm{mL}$ respectively. Different surface tension reduction and cmc values of biosurfactants have been reported by various authors and biosurfactants with surface tension reduction up to $35 \mathrm{dynes} / \mathrm{cm}$ and $\mathrm{cmc}$ between 1 and $150 \mathrm{mg} / \mathrm{L}$ are reported to be good biosurfactants [7]. This indicates that the best two bio-molecules in our study are effective and efficient and therefore suitable for their desired applications.

Different solvents and/or their mixtures have been adopted for biosurfactant isolation depending on the chemical nature of the biosurfactant. In this study, acidification, followed by solvent extraction with chloroform:methanol recovered $4.39 \mathrm{~g} / \mathrm{L}$ of crude biosurfactant. The successful recovery of biosurfactants from cell-free fermentation broth by this method had earlier been reported by Onbasli and Aslim [36].

Biochemical characterizations, thin layer chromatography, high performance liquid chromatography and Fourier transform-infrared (FTIR) spectrometry identified surface-active compound by Bacillus cereus strain R15B as a lipopeptide (data not shown) and that from Pseudomonas aeruginosa strain IKW1 as a polymeric compound composed of $40.36 \%$ carbohydrates, $20.16 \%$ proteins and $32.56 \%$ lipids. As far as we know, this is the third report on the ability of a strain of Pseudomonas aeruginosa to produce a glycolipopeptide (or peptidoglycolipid) biosurfactant. The first appearance of this report came from Koronelli et al. [37] while the second came from Ilori and Amund [38]. This therefore contradicts the speculation that Pseudomonas aeruginosa only produces rhamnolipid (glycolipid) type of biosurfactant. Two decades before the brilliant review of Desai and Banat [7] on biosurfactants, a strain of Pseudomonas aeruginosa
[39] was reported to produce a protein-like activator PA for n-alkane oxidation. Thavasi et al. [21] recently isolated a strain of Pseudomonas aeruginosa from salt-water that produces a lipopeptide biosurfactant. The implication of these is that different strains of Pseudomonas aeruginosa obtained from different samples at different climatic and ecological conditions would produce surface-active compounds of differing chemical nature and composition to facilitate their competitiveness in those environments.

The commercial applications of biosurfactants are intrinsically related to their activities and a number of such activities were investigated in our study. The washing activity of the glycolipopeptide investigated by the sand pack method at different temperatures was targeted at demonstrating the oil recovery potential of the biosurfactant. The dual influences of holding time and temperature on the recovery rate of Nigerian medium crude oil at a constant biosurfactant concentration were significant $(\mathrm{P}<0.05)$. Our results of $79.92 \%$ recovery of the oil at $70^{\circ} \mathrm{C}$ with the highest elution rate of $0.68 \mathrm{~mL} / \mathrm{min}$ occurring at 90 min suggests sublime efficiency of the glycolipopeptide to recover crude oil from producing and abandoned oil reservoirs.

The ability of hydrophobic organic compounds to be solubilized and transported into the immediate vicinity of bacterial cells capable of metabolizing (degrading) them is potentially the rate-limiting step in bioremediation [40]. The underpinning activities of microorganisms able to degrade hydrophobic organic compounds include solubilization; which makes the compound bio-available, and emulsification; which makes the compound bio-accessible, to the bioremediating microorganisms. The solubilization ability of our study glycolipopeptide was excellent increasing with glycolipopeptide concentration and suggesting significant $(P=0.000)$ influence of biosurfactant on the amount of oil solubilized. The linear regression model used to fit the data revealed that $99.01 \%$ of the solubilized oil was due to the biosurfactant and that $0.99 \%$ of the dissolved oil would be due to other factors especially water and temperature. The glycolipopeptide in this study was able to emulsify kerosene, crude oil and palm oil to emulsification indices of $79.71 \%, 84.87 \%$ and $87.54 \%$ respectively. Our results are in agreement with those of a glycolipopeptide produced by Bacillus sp.E34 [18] with similar emulsification index of $77 \%$ in kerosene and $84.5 \%$ in crude oil. Our results of soil washing experiment as well as those of solubilization and emulsification indicate the potentials for application of our glycolipopeptide in enhanced oil recovery, remediation of environments polluted with petroleum and petroleum products as well as treatment of palm oil effluents. 
The usefulness of biosurfactants with antimicrobial properties in bioremediation of hydrocarbonimpacted ecosystems has been a research question in our labouratory for some time. Inhibitory activity of our glycolipopeptide against Bacillus subtilis UCCM 0006; a most potent crude oil degrader in the University of Calabar Collection of Microorganisms (UCCM) goes to suggest the non-suitability of this surface-active compound for bioremediation when the major remediating organism is Bacillus subtilis. Interestingly, the biosurfactant was metabolized by Serratia sp. Strain DW2 (100\% sequence homology with Serratia sp. Strain ZJ-I- JQ954966A) as sole source of carbon and energy and so demonstrated no antimicrobial activity against it. This indicates the biodegradability potential of the biosurfactant and suggests its suitability for applications in environments dominated by this bacterium. The antimicrobial potentials of our biosurfactant suggest the need for microbiological characterization of hydrocarbon-polluted sites before biosurfactantenhanced remediation attempt.

A property that is immediately visible upon agitation of a biosurfactant solution is foaming and this is characteristic of all detergents. The glycolipopeptide under study was found to demonstrate excellent foaming power and therefore excellent detergency. The small densely-packed foam ensured strong intermolecular forces responsible for the attraction of the foam molecules together ensuring good activity and stability; a property that facilitates emulsion formation and stabilization of the surface-active compound. The foam power and its stability for more than $48 \mathrm{~h}$ suggest suitability for applications in the detergent and food industries.

The oil displacement activity of a biosurfactant is a property that ensues as the contact angle at the oilwater interface is changed by a surface-active compound and varies directly with the amount of biosurfactant in the sample. The more the active compound at the oil-water interface the more its pressure; the more the pressure the lower the contact angle and the greater the solubilization of the hydrophobic component in the solvent. This activity is therefore a rapid indirect assessment of the solubilization potential of a biosurfactant and its stability to the influences of temperature, $\mathrm{pH}$ and $\mathrm{NaCl}$ is essential for oil recovery and bioremediation exercises. The oil displacement activity of the glycolipopeptide in this study was significantly stable to temperatures up to $80^{\circ} \mathrm{C}$ and $\mathrm{pH}$ from 7 to 9 but decreased linearly with increase in $\mathrm{NaCl}$ concentrations. These, in consonance with its oilwashing activity, suggest the suitability of the surface-active compound for biosurfactant-enhanced recovery of crude oil.
On the other hand, the emulsification activity of the glycolipopeptide increased with increase in temperature indicating the thermal stability of the bonds involved in the formation of the polymer. The emulsions formed at high temperatures, with kerosene as the hydrophobic compound, were stable for more than 4 months at the ambient conditions of our labouratory. The emulsifying ability of the glycolipopeptide was stable over a wide range of $\mathrm{pH}$ values (6-10 for kerosene and 7-10 for palm oil) but decreased gradually with increasing $\mathrm{NaCl}$ concentrations. Only $23.47 \%$ of the emulsifying activity of the biosurfactant was lost at $10 \% \mathrm{NaCl}$ concentration which underpins the suitability of the compound for tertiary recovery of oil.

The antimicrobial activity of the glycolipopeptide was stable up to $60^{\circ} \mathrm{C}$ and decreased as temperature increased. The loss of antimicrobial activity at this temperature and the stability or improvement of oil displacement and emulsifying activities suggests the probable loss of the peptide moiety of the glycolipopeptide and its possible non-requirement for emulsifying activity. This is at variance with the hypothesis that protein moiety is responsible for the emulsifying activity of biosurfactants [41]. If this was so, then rhamnolipids would have no emulsifying activities. $\mathrm{pH}$ and $\mathrm{NaCl}$ significantly $(P<0.05)$ affected the antimicrobial property of the glycolipopeptide, nevertheless, the activity was stable at alkaline $\mathrm{pH}$ and $\mathrm{NaCl}$ concentrations below $10 \%$. Acidic $\mathrm{pH}$ values have been shown to influence the electrostatic interactions between polar head groups of biosurfactant molecules [42]. This suggests the applicability of the surface-active compound for antimicrobial coverage in preparations of food and pharmaceutical formulations where emulsion developments are desirable.

\section{Conclusion}

Pseudomonas aeruginosa Strain IKW1 was isolated from the mesotidal waters of Ikang River, Niger Delta area, Nigeria and demonstrated commendable ability to elaborate a rare but effective and efficient surface-active compound identified as a glycolipopeptide. The active compound demonstrated excellent properties of oil washing, solubilization, emulsification, foaming and antimicrobial action. These activities were stable at moderately high temperatures, alkaline $\mathrm{pH}$ and $\mathrm{NaCl}$ concentrations below $10 \%$. The bacterium is recommended for large-scale production of the biosurfactant on waste frying oil as a restaurant waste management option and for applications in tertiary oil recovery, bioremediation of hydrocarbon-impacted environments and the development of detergent, food and pharmaceutical preparations where emulsion development, stabilization and preservation are 
desired.

\section{Acknowledgements}

The authors are grateful for the research grant by the government of Cross River State through their Ministry of Education and to Professor O. E. Fagade of the University of Ibadan, Nigeria for facilitating the high performance liquid chromatographic (HPLC) and Fourier transform-infrared (FT-IR) spectrometric analyses of the biosurfactant.

\section{References}

1) Al-Araji, L., Rahman, R.N.Z.R.A., Basri, M. and Salleh, A.B. (2007) Microbial surfactants, Asian Pacific Journal of Molecular Biology and Biotechnology, 15, 99-105.

2) Banat, I.M., Franzetti, A., Gandolfi, I., Bestetti, G., Martinotti, M.G., Fracchia, L., Smyth, T.J. and Marchant, R. (2010) Microbial biosurfactants production, applications and future potential, Applied Microbiology and Biotechnology, 87, 427- 444. http://dx.doi.org/10.1007/s00253-010-2589-0

3) Pacwa-Plociniczak, M., Plaza, G.A., Piotrowska-Seget, Z. and Cameotra S.S. (2011) Environmental applications of biosurfactants: recent advances. International Journal of Molecular Sciences, 12, 633-654. http://dx.doi.org/10.3390/ijms12010633

4) Sachdev, D.P. and Cameotra, S.S. (2013) Biosurfactants in agriculture. Applied Microbiology and Biotechnology, 97, 1005-1016. http://dx.doi.org/10.1007/s00253-012-4641-8

5) Lawniczak, L., Marecik, R. and Chrzanowski, L. (2013) Contribution of biosurfactants to natural or induced bioremediation. Applied Microbiology and Biotechnology, 97, 2327-2339. http://dx.doi.org/10.1007/s00253-013-4740-1

6) Morikawa, M., Daido, H., Takao, T., Murata, S., Shimonishi, Y. and Imanaka, T. (1993) A new lipopeptide biosurfactant produced by Arthrobacter sp. Strain MIS38. Journal of Bacteriology, 175, 6459-6466.

7) Desai, J.D. and Banat, I.M. (1997). Microbial production of surfactants and their commercial potential, Microbiology and Molecular Biology Reviews, 61, 47-64.

8) Thavasi, R.S., Jayalakshmi, L., Balasubramaian, T. Banat I M. (2007) Biosurfactants production by Corynebacterium kutscheri from waste motor lubricant oil and peanut oil cake. Letters in Applied Microbiology, 45, 686-691. http://dx.doi.org/10.1111/j.1472-765X.2007.02256.x

9) Banat, I.M., Makkar, R.S. and Cameotra, S.S. (2000) Potential commercial applications of microbial surfactants. Applied Microbiology and Biotechnology, 53, 495-508. http://dx.doi.org/10.1007/s002530051648

10) Mulligan, C.N. (2005) Environmental applications for biosurfactants. Environmental Pollution, 133, 183-198. http://dx.doi.org/10.1016/j.envpol.2004.06.009

11) Franzetti, A., Tamburini, E. and Banat, I.M. (2010) Applications of biological surface active compounds in remediation technologies. Advances in Experimental Medicine and Biology, 672, 121-34. http://dx.doi.org/10.1007/978-1-4419-5979-9_9

12) Lima, T.M., Procópio, L.C., Brandão, F.D, Leão, B.A., Tótola, M.R. and A.C. Borges, A.C. (2011) Evaluation of bacterial surfactant toxicity towards petroleum-degrading microorganisms. Bioresource Technology, 102, 2957-2964. http://dx.doi.org/10.1016/j.biortech.2010.09.109

13) Bodour, A.A., Drecs, K.P. and Maier, R.M. (2003) Distribution of biosurfactant-producing bacteria in undisturbed and contaminated arid southwestern soils. Applied and Environmental Microbiology, 69, 3280-3287. http://dx.doi.org/10.1128/AEM.69.6.3280-3287.2003

14) Satpute, S.K., Bhawsar, B.D., Dhakephalkar, P.K. and Chopade, B.A. (2008) Assessment of different screening methods for selecting biosurfactant producing marine bacteria. Indian Journal of Marine Sciences, 37, 243-250.
15) Daverey, A., Pakshirajan, K. and Sangeetha, P. (2009) Sophorolipids production by Candida bombicola using synthetic dairy wastewater, International Journal of Environmental Science and Engineering, 1, 173-175.

16) Savergave, L.S., Gadre, R.V., Vaidya, B.K. and Narayanan, K. (2011) Strain improvement and statistical media optimization for enhanced erythritol production with minimal by-products from Candida magnoliae mutant R23. Biochemical Engineering Journal, 55, 92-100. http://dx.doi.org/10.1016/j.bej.2011.03.009

17) Kiran, G.S., Selvin, J., Manilal, A. and Sujith, S. (2011) Biosurfactants as green stabilizers for the biological synthesis of nanoparticles. Critical Reviews in Biotechnology, 31, 354364. http://dx.doi.org/10.3109/07388551.2010.539971

18) Mabrouk, M.E.M., Youssif, E.M. and Sabry, S.A. (2014) Biosurfcatant production by a newly isolated soft coralassociated marine Bacillus sp.E34: Statistical optimization and characterization, Life Science Journal, 11, 756-768.

19) Nitschke, M., Ferraz, C. and Pastore, G.M. (2004) Selection of microorganisms for biosurfactant production using agroindustrial wastes. Brazilian Journal of Microbiology, 35, 8185. http://dx.doi.org/10.1590/S1517-83822004000100013

20) Rodrigues, L.R., Teixeira, J.A. and Oliveira, R. (2006) Lowcost fermentative medium for biosurfactant production by probiotic bacteria. Biochemical Engineering Journal, 32, 135142. http://dx.doi.org/10.1016/j.bej.2006.09.012

21) Thavasi, R.S., Subramanyam Nambaru, V.R.M., Jayalakshmi, S., Balasubramanian, T. and Banat, I.M. (2011) Biosurfactant production by Pseudomonas aeruginosa from renewable resources. Indian Journal of Microbiology, 51, 3036. http://dx.doi.org/10.1007/s12088-011-0076-7

22) Asitok, A.D. and Antai, S.P. (2006) Petroleum hydrocarbon utilization and biosurfactant production by Pseudomonas and Bacillus species. Nigerian Journal of Microbiology, 20, 824831.

23) Lindahl, M., Faris, A., Wadstrom, T. and Hjerten, S. (1981) A new test based on salting out to measure relative surface hydrophobicity of bacterial cells. Biochemistry and Biophysics Acta, 677, 471- 476 . http://dx.doi.org/10.1016/0304-4165(81)90261-0

24) Queiroga, C.L., Nascimento, L.R. and Serra, G.E. (2003) Evaluation of paraffins biodegradation and biosurfactant production by Bacillus subtilis in the presence of crude oil. Brazilian Journal Microbiology, 34, 321-324. http://dx.doi.org/10.1590/S1517-83822003000400006

25) Dubois, M., Gilies, K.A., Hamilton, J.K., Rebers, P.A. and Smith, F. (1956) Colorimetric method for determination of sugar and related substances, Analytical Chemistry, 28, 350356. http://dx.doi.org/10.1021/ac60111a017

26) Bradford, M.M. (1976) A rapid and sensitive method for the quantitation of microgram quantities of protein utilizing the principle of protein-dye binding, Analytical Biochemistry, 72, 248-254. http://dx.doi.org/10.1016/0003-2697(76)905273

27) Folch, J.M., Lees, M. and Stanly, H.S. (1956) A simple method for the isolation and quantification of total lipids from animal tissues. Journal of Biological Chemistry, 226, 497-509

28) Fernandes P A V, Renata de Arruda I, Botelho dos Santos A F A, Albertina de Araujo A, Maior A M S and Ximenes, E.A. (2007) Antimicrobial activity of surfactants produced by Bacillus subtilis R14 against multidrug-resistant bacteria. Brazilian Journal of Microbiology, 38, 704-709. http://dx.doi.org/10.1590/S1517-83822007000400022

29) Berry, C., Dilantha Fernando, W.G., Loewen, P.C. and de Kievit, T.R. (2010) Lipopeptides are essential for Pseudomonas sp. DF41 biocontrol of Sclerotinia sclerotiorum. Biological Control, 55, 211-218. http://dx.doi.org/10.1016/j.biocontrol.2010.09.011

30) Kiran, G.S., Thomas, T.A., Selvin, J., Sabarathnam, B. and Lipton, A.P. (2010) Optimization and characterization of a new lipopeptide biosurfactant produced by marine Brevibacterium aureum MSA13 in solid state culture. 
Bioresource Technology, 101, 2389-2396. http://dx.doi.org/10.1016/j.biortech.2009.11.023

31) Whang, L.M., Liu, P.W.G., Ma, C.C. and Cheng, S.S. (2008) Application of biosurfactants; rhamnolipid and surfactin, for enhanced biodegradation of diesel-contaminated water and soil, Journal of Hazardous Materials, 151 155-163. http://dx.doi.org/10.1016/j.jhazmat.2007.05.063

32) Chen, Y., Yang, C., Chang, M., Ciou, Y. and Huang, Y. (2010) Foam properties and detergent abilities of the saponins Camellia oleifera, International Journal of Molecular Sciences, 11, 4417-4425. http://dx.doi.org/10.3390/ijms11114417

33) Abouseoud, M., Maachi, R., Amrane, A., Boudergua, S. and Nabi, A. (2008) Evaluation of different carbon and nitrogen sources in production of biosurfactant by Pseudomonas fluorescens, Desalination, 223, 143-151. http://dx.doi.org/10.1016/j.desal.2007.01.198

34) Makkar, R.S., Cameotra, S.S. and Banat, I.M. (2011) Advances in utilization of renewable substrates for biosurfactant production, AMB Express, 1, 5. http://dx.doi.org/10.1186/2191-0855-1-5

35) Karanth, N.G.K., Deo, P.G. and Veenanadig, N.K. (1999) Microbial biosurfactants and their importance, Current Science, $77,116-126$

36) Onbasli, D. and Aslim, B. (2009) Biosurfactant production in sugar beet molasses by some Pseudomonas spp. Journal of Environmental Biology, 30, 161-163
37) Koronelli, T.V., Komarova, T.I and Denisov, luV. (1983) Chemical composition and role of Pseudomonas aeruginosa peptidoglycolipid in hydrocarbon assimilation, Mikrobiologiia, 52, 767-770

38) Ilori, M.O. and Amund, D.I. (2001) Production of a peptidoglycolipid bioemulsifier from Pseudomonas aeruginosa grown on hydrocarbon. Z Naturforsch C, 56, 547552. http://dx.doi.org/10.1515/znc-2001-7-812

39) Hisatsuka, K., Nakahara, T., Minoda, Y. and Yamada, K. (1977). Formation of protein-like activator for n-alkane oxidation and its properties, Agricultural and Biological Chemistry, 41, 445-450 http://dx.doi.org/10.1271/bbb1961.41.445 http://dx.doi.org/10.1080/00021369.1977.10862518

40) Cohen, Y. (2002) Bioremediation of oil by marine microbial mats. International Microbiology, 5, 189-193. http://dx.doi.org/10.1007/s10123-002-0089-5

41) Sekhon, K.K.., Khanna, S. and Cameotra, S.S. (2012) Biosurfactant production and potential correlation with esterase activity. Journal of Petroleum and Environmental Biotechnology, 3, 333-343.

42) Gupta, R., Gupta, N. and Rathi, P. (2004) Bacterial lipases: an overview of production, purification and biochemical properties. Applied Microbiology and Biotechnology, 64, 763-781. http://dx.doi.org/10.1007/s00253-004-1568-8

Table 1. Distribution of biosurfactant-producing bacteria in samples as assessed by the rapid-drop collapse test

\begin{tabular}{|c|c|c|c|c|c|c|c|c|}
\hline $\mathrm{S} / \mathrm{N}$ & Samples & nCAHB & gMSM & glMSM & rpeMSM & coMSM & wfoMSM & Total \\
\hline 1 & DW & 38 & 0 & 1 & 0 & 2 & 3 & 6 \\
\hline 2 & DS & 67 & 0 & 0 & 1 & 5 & 2 & 8 \\
\hline 3 & FSW & 43 & 0 & 0 & 0 & 0 & 1 & 1 \\
\hline 4 & FSS & 38 & 0 & 0 & 2 & 0 & 3 & 5 \\
\hline 5 & EW & 46 & 3 & 2 & 2 & 2 & 2 & 11 \\
\hline 6 & $\mathrm{ES}$ & 63 & 4 & 2 & 4 & 1 & 2 & 13 \\
\hline 7 & MW & 33 & 2 & 0 & 1 & 1 & 1 & 5 \\
\hline 8 & MS & 45 & 1 & 1 & 2 & 0 & 2 & 6 \\
\hline 9 & SCW & 36 & 0 & 0 & 3 & 2 & 5 & 10 \\
\hline 10 & SCS & 39 & 1 & 1 & 2 & 1 & 2 & 7 \\
\hline 11 & IKW & 65 & 0 & 0 & 1 & 3 & 1 & 5 \\
\hline 12 & IFW & 96 & 0 & 1 & 0 & 4 & 1 & 6 \\
\hline 13 & GS-A & 50 & 1 & 1 & 2 & 0 & 5 & 9 \\
\hline 14 & GS-B & 69 & 3 & 0 & 0 & 0 & 0 & 3 \\
\hline 15 & WA & 23 & 0 & 1 & 0 & 3 & 3 & 7 \\
\hline 16 & WB & 29 & 0 & 0 & 0 & 2 & 6 & 8 \\
\hline 17 & LPS & 32 & 1 & 3 & 1 & 4 & 1 & 10 \\
\hline 18 & $\mathrm{R} 15$ & 23 & 0 & 0 & 0 & 6 & 2 & 8 \\
\hline 19 & $\mathrm{R} 4$ & 16 & 1 & 0 & 0 & 0 & 6 & 7 \\
\hline \multirow[t]{2}{*}{20} & COS & 7 & 2 & 1 & 0 & 1 & 2 & 6 \\
\hline & TOTAL & 858 & 19 & 14 & 21 & 37 & 50 & 141 \\
\hline
\end{tabular}

nCAHB-number of culturable aerobic heterotrophic bacteria; R15-Reservoir 15; R4-Reservoir 4; gMSM-glucose + mineral salts medium; glMSM-glycerol + mineral salts medium; rpeMSM-rice processing effluent + mineral salts medium; coMSM-crude oil + mineral salts medium; wfoMSM-waste frying oil + mineral salts medium; DWDouglas creek water; DS-Douglas creek sediment; FSW-Flare station water; FSS-Flare station sediment; EW-Eketai water; ES-Eketai sediment; MW-Mkpanak water; MS-Mkpanak sediment; SCW-Stubbs creek water; SCS-Stubbs creek sediment; IKW-Ikang water; IFW-Ifondo water; GSA-Garden soil A; GSB-Garden soil B; WA-Mechanic workshop soil A; WB-Mechanic workshop soil B; LPS-Lubricating oil polluted soil; R15-Reservoir 15 oil formation water; R4-Reservoir 4 oil formation water; COS-crude oil sample 
Table 2. Quantitative screening of biosurfactant-producing bacteria from samples as assessed by the oil displacement assay

\begin{tabular}{cccccc}
\hline & Water & \multicolumn{2}{c}{ Sediment } & & Soil \\
Isolate & Amount $\left(\mathrm{cm}^{2}\right)$ & Isolate & Amount $\left(\mathrm{cm}^{2}\right)$ & Isolate & Amount $\left(\mathrm{cm}^{2}\right)$ \\
\hline IKW1 & $66.5 \pm 1.8$ & ES2 & $31.2 \pm 0.6$ & WA3 & $24.6 \pm 1.1$ \\
IFW3 & $55.3 \pm 1.2$ & SS1 & $17.3 \pm 0.7$ & LPS1 & $23.7 \pm 0.6$ \\
OB6 & $52.8 \pm 1.2$ & MS2 & $17.3 \pm 1.2$ & WA4 & $22.0 \pm 0.5$ \\
R15B & $50.3 \pm 2.2$ & DS2 & $15.2 \pm 1.3$ & WB1 & $21.2 \pm 1.1$ \\
DW2 & $40.2 \pm 0.7$ & ES4 & $13.8 \pm 0.7$ & LPS2 & $21.2 \pm 0.8$ \\
EW2 & $38.1 \pm 0.5$ & SS2 & $13.8 \pm 0.2$ & WA6 & $18.1 \pm 0.9$ \\
SW1 & $32.0 \pm 0.4$ & MS5 & $10.7 \pm 0.9$ & & \\
R15A & $30.2 \pm 0.6$ & & & & \\
OB3 & $28.9 \pm 1.3$ & & & & \\
MW2 & $21.2 \pm 0.3$ & & & & \\
OB1 & $16.6 \pm 0.4$ & & & & \\
EW5 & $16.6 \pm 1.2$ & & & & \\
DW1 & $13.2 \pm 1.2$ & & & & \\
EW3 & $11.9 \pm 0.8$ & & & & \\
EW6 & $11.3 \pm 1.5$ & & & & \\
\hline
\end{tabular}

DW-Douglas creek water; DS-Douglas creek sediment; EW-Eketai water; ES-Eketai sediment; IKW-Ikang water; IKS-Ikang sediment; MW-Mkpanak water; MS-Mkpanak sediment; OB-Crude oil bacteria; R15-Reservoir 15 water; SW-Stubbs creek water; SS-Stubbs creek sediment; WA-mechanic workshop soil A; WB-Mechanic workshop soil

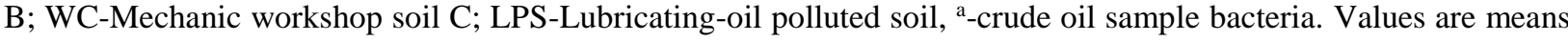
of triplicate determinations \pm standard deviation.

Table 3. Identities of selected biosurfactant-producing bacteria

\begin{tabular}{|c|c|c|c|c|c|}
\hline $\mathrm{S} / \mathrm{N}$ & $\begin{array}{l}\text { Isolate } \\
\text { code }\end{array}$ & $\begin{array}{l}\text { Gram } \\
\text { reaction }\end{array}$ & Identity & $\begin{array}{l}\text { Close relative with \% similarity and } \\
\text { accession number }\end{array}$ & $\begin{array}{l}\text { Isolating carbon } \\
\text { source }\end{array}$ \\
\hline 1 & DW2 & - & Serratia sp. & 100\% Serratia sp. ZJ-I (JQ954966A) & $\begin{array}{l}\text { Crude oil and waste } \\
\text { frying oil }\end{array}$ \\
\hline 2 & IKW1 & - & $\begin{array}{l}\text { Pseudomonas } \\
\text { aeruginosa }\end{array}$ & $\begin{array}{c}\text { 100\% Pseudomonas aeruginosa strain } \\
\text { HNYM41 (JN999891A) }\end{array}$ & $\begin{array}{l}\text { Glycerol, crude oil } \\
\text { and waste frying oil }\end{array}$ \\
\hline 3 & IFW3 & - & $\begin{array}{l}\text { Pseudomonas } \\
\text { flourescens. }\end{array}$ & $96 \%$ Pseudomonas fluorecens $-25^{\mathrm{b}}$ & $\begin{array}{l}\text { Crude oil and waste } \\
\text { frying oil }\end{array}$ \\
\hline 4 & OB6 & - & $\begin{array}{l}\text { Pseudomonas } \\
\text { sp. }\end{array}$ & $\begin{array}{c}\text { 100\% Pseudomonas sp. RPT-52 } \\
\text { (JF756593A) }\end{array}$ & $\begin{array}{c}\text { Glycerol, rice } \\
\text { processing effluent } \\
\text { and waste frying oil }\end{array}$ \\
\hline 5 & R15B & + & $\begin{array}{l}\text { Bacillus } \\
\text { cereus }\end{array}$ & $\begin{array}{c}\text { 100\% Bacillus cereus strain F2 } \\
\text { (JQ579629A) }\end{array}$ & $\begin{array}{l}\text { Glucose, crude oil and } \\
\text { waste frying oil }\end{array}$ \\
\hline 6 & LPS1 & + & Bacillus sp. & 99\% Bacillus sp. ABO1 (JX094300A) & $\begin{array}{l}\text { Glycerol, crude oil } \\
\text { and waste frying oil }\end{array}$ \\
\hline
\end{tabular}

DW-Douglas creek water; IKW-Ikang water; IFW3-Ifondo water; OB-Crude oil bacteria; R15-Reservoir 15 water; LPS-Lubricating-oil polluted soil. ${ }^{\mathrm{b}}$ isolate identified with Microgen ID kit, incomplete 16S rRNA sequencing, accession number not yet obtained. 


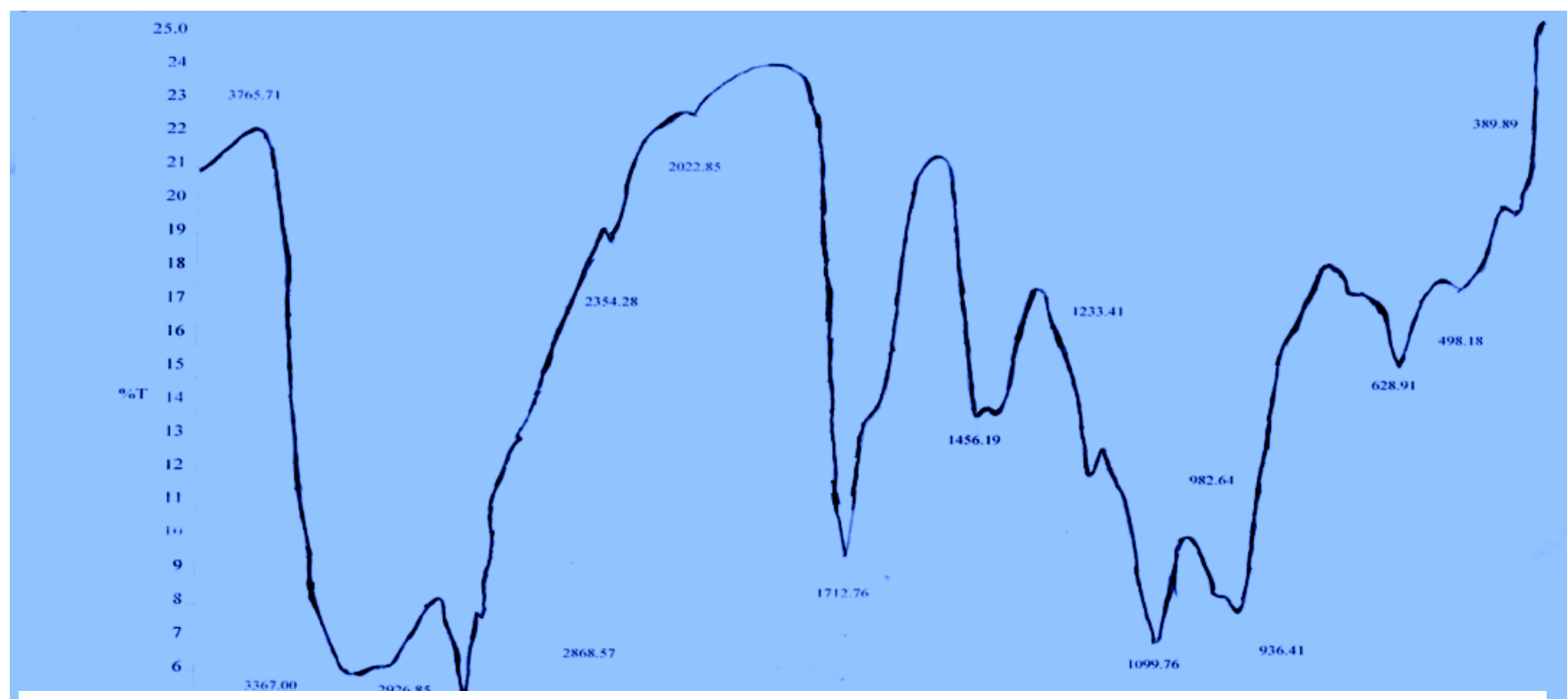

Figure 1. Spectrum of Pseudomonas aeruginosa strain IKW1 glycolipopeptide biosurfactant from Fourier-transform infrared (FT-IR) spectrometry obtained by plotting \% transmittance (y-axis) against wave numbers in $\mathrm{cm}^{-1}(\mathrm{x}-$ axis)

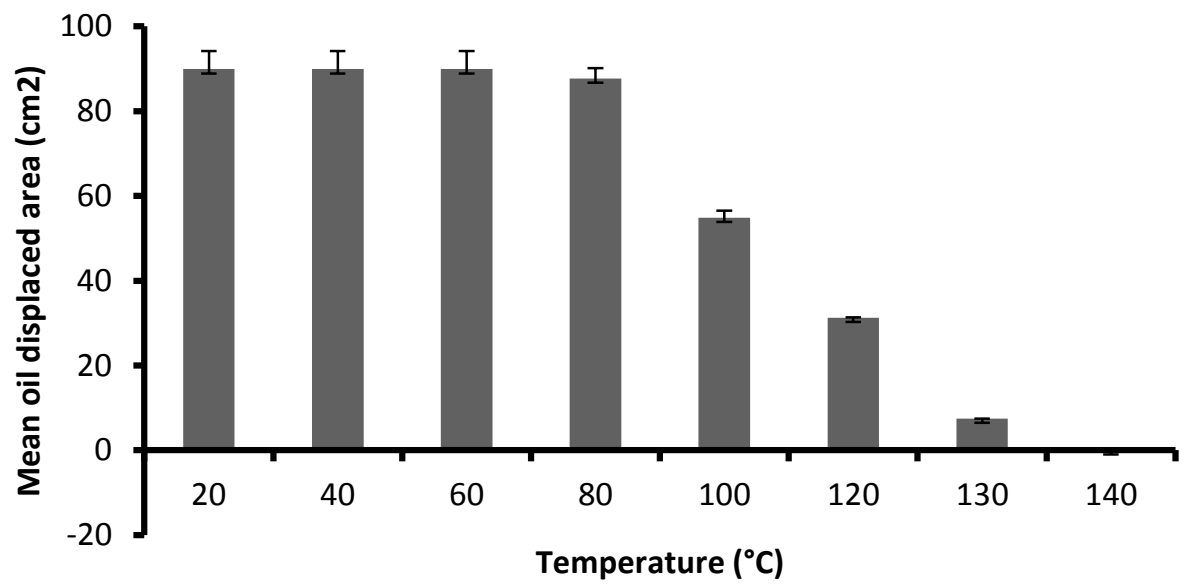

A

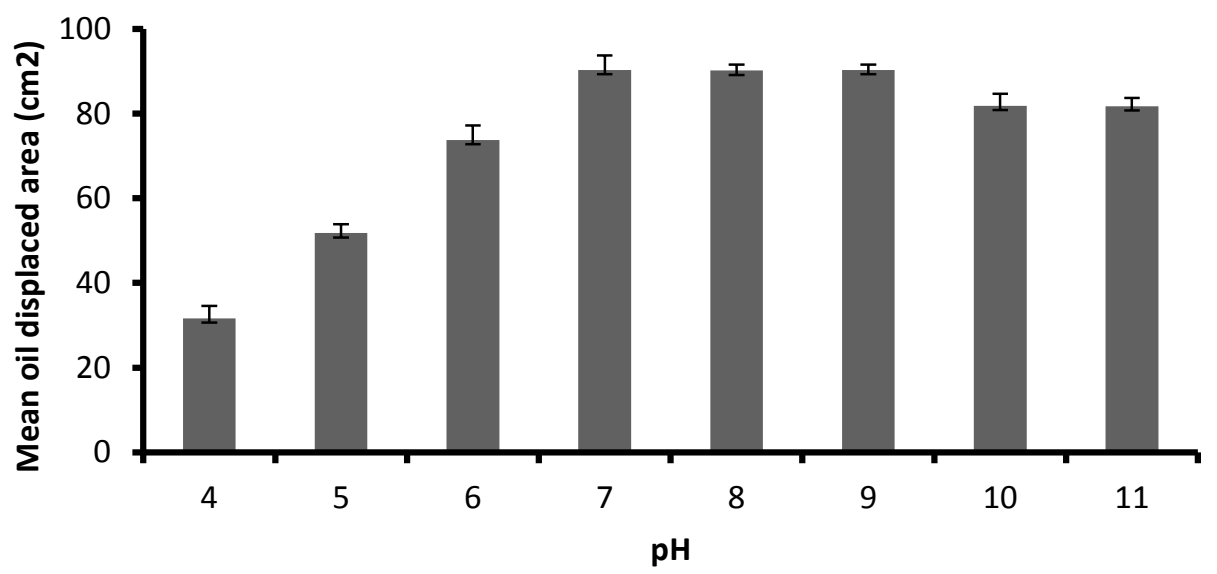




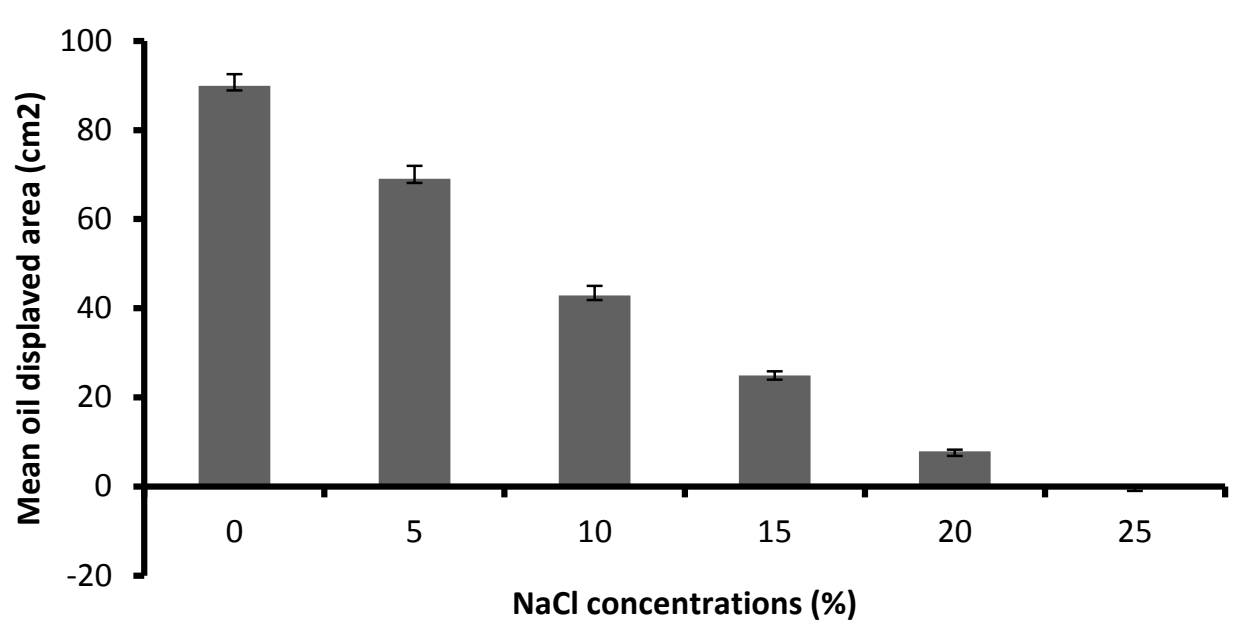

C

Figure 2. Stability of glycolipopeptide oil displacement activity to (A), temperature (B) pH (C) $\mathrm{NaCl}$

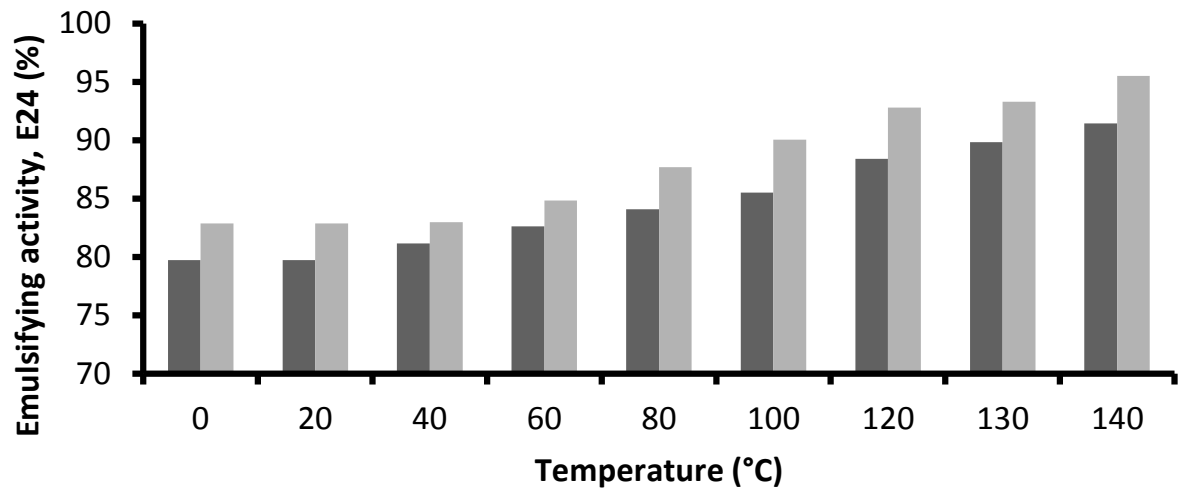

A

Kerosene Palm oil

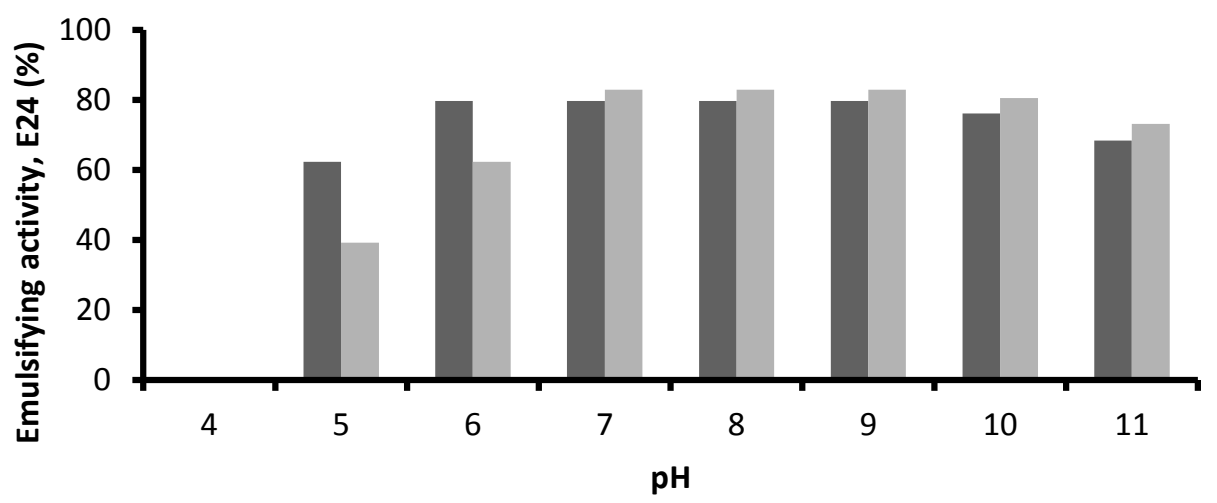

B

Kerosene Palm oil 


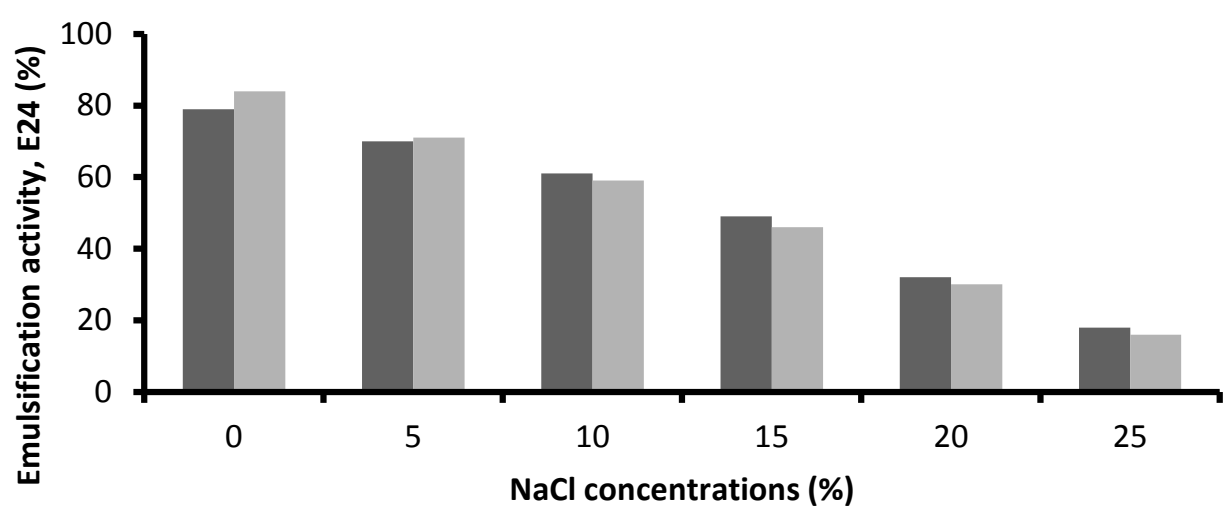

- Kerosene Palm oil

Figure 3. Stability of glycolipopeptide emulsifying activity to (A) Temperature (B) pH (C) NaCl
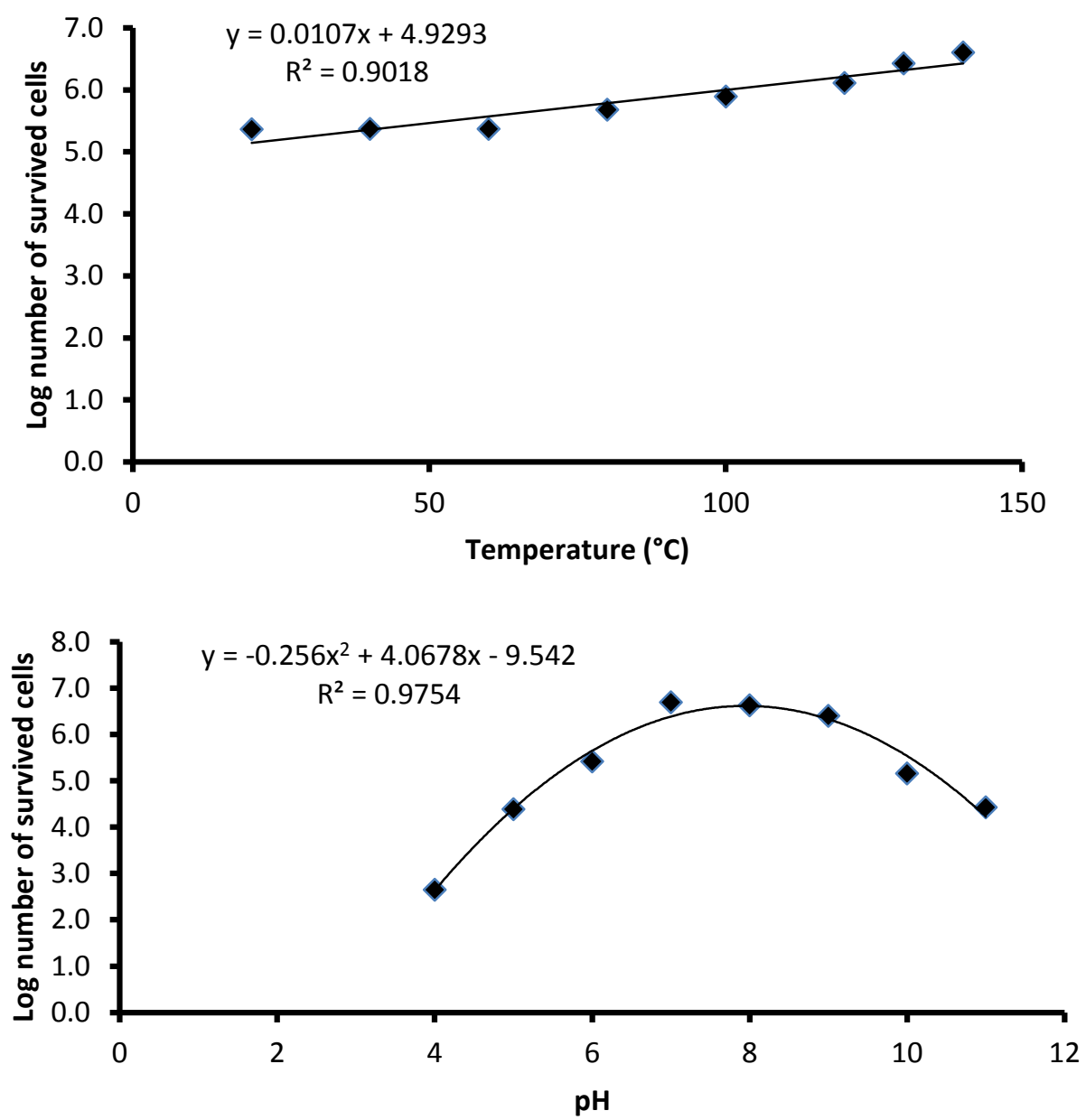


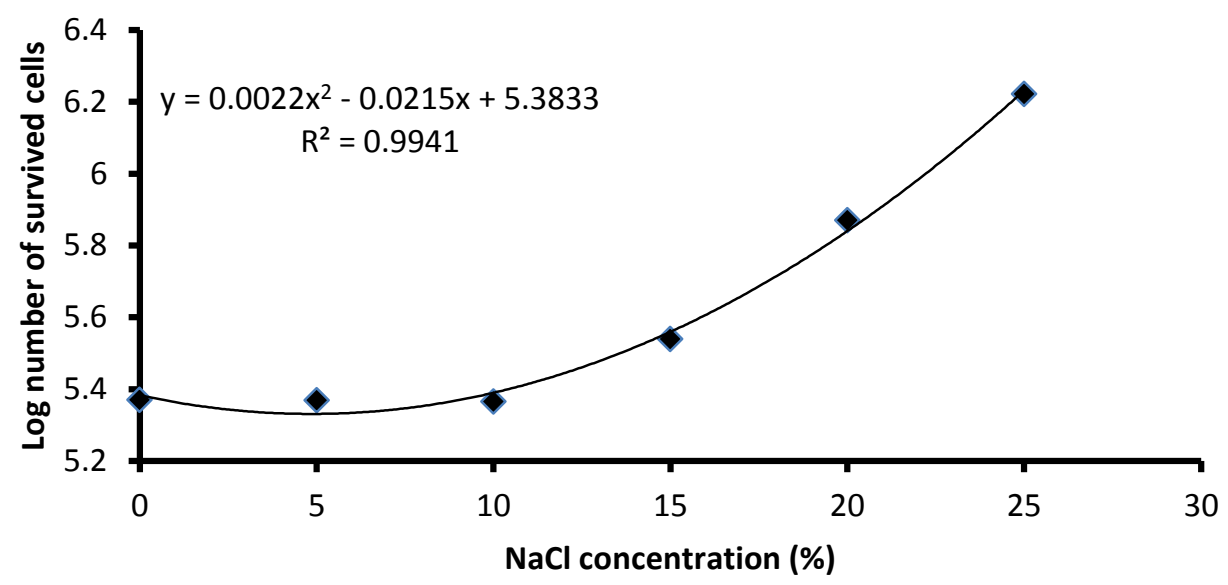

C

Figure 4. Stability of glycolipopeptide antibacterial activity to (A) temperature (B) $\mathrm{pH}$ (C) $\mathrm{NaCl}$ 